\title{
Interaction of Calf Thymus DNA with the Ni(II) Complex of Sodium 1,4-Dihydroxy-9,10-Anthraquinone-2-Sulphonate: A Novel Method of Analysis Using Cyclic Voltammetry
}

\author{
Partha Sarathi Guin, ${ }^{1,2,3}$ Piyal Das, ${ }^{2}$ Saurabh Das, ${ }^{2}$ and Parikshit Chandra Mandal ${ }^{1}$ \\ ${ }^{1}$ Chemical Sciences Division, Saha Institute of Nuclear Physics, 1/AF-Bidhannagar, Kolkata 700064, India \\ ${ }^{2}$ Department of Chemistry, Jadavpur University, Raja S. C. Mullick Road, Kolkata 700032, India \\ ${ }^{3}$ Department of Chemistry, Shibpur Dinobundhoo Institution (College), 412/1 G. T. Road (South), Howrah 711102, India
}

Correspondence should be addressed to Saurabh Das, dasrsv@yahoo.in

Received 15 February 2011; Accepted 20 April 2011

Academic Editor: Rene Kizek

Copyright ( $) 2012$ Partha Sarathi Guin et al. This is an open access article distributed under the Creative Commons Attribution License, which permits unrestricted use, distribution, and reproduction in any medium, provided the original work is properly cited.

\begin{abstract}
Hydroxy-9,10-anthraquinones are cheaper alternatives to anthracycline drugs. They closely resemble anthracycline drugs both from a structural and functional viewpoint. Electrochemical behavior of the $\mathrm{Ni}(\mathrm{II})$ complex $\left(\mathrm{Na}_{2}\left[\mathrm{Ni}\left(\mathrm{NaLH}_{2} \mathrm{Cl}_{2}\right] \cdot 2 \mathrm{H}_{2} \mathrm{O}\right)\right.$ of sodium 1,4-dihydroxy-9,10-anthraquinone-2-sulphonate $\left(\mathrm{NaLH}_{2}\right)$, analogue of the core unit of anthracycline anticancer drugs, was studied at physiological $\mathrm{pH}$ using cyclic voltammetry. The $\mathrm{Ni}$ (II) complex of sodium 1,4-dihydroxy-9,10-anthraquinone2-sulphonate undergoes diffusion-controlled one-electron reduction that enables performing an electrochemical study on the interaction of the complex with calf thymus DNA. The complex was titrated with increasing concentrations of DNA, and the reduction peak for the unbound complex helped in evaluating binding parameters. Analysis of binding data using nonlinear curve fit in a cyclic voltammetry experiment is the first such attempt. The paper evaluates site size of interaction that also serves as a means to determine stoichiometry of complex formation, between a metal ion and ligand from a DNA interaction study, probably a first of its kind.
\end{abstract}

\section{Introduction}

Anthracycline drugs, the most widely used anticancer agents $[1,2]$, get limited in their use due to high cost and cardiotoxic properties $[3,4]$. Although the exact mechanism by which anthracyclines exert their anticancer activity is still uncertain [5], dominant amongst various mechanisms appear to involve impairment of topoisomerase-II $\alpha$ activity $[6,7]$, that is consistent with observed DNA intercalation and nuclear localization of the drug [8-10]. Biochemical studies show that the drugs inhibit both DNA-directed DNA synthesis [11] and DNA-directed RNA synthesis [12], presumably by their ability to interact with the DNA template primer $[13,14]$. Owing to aforesaid reasons, research on the interaction of anthracyclines and their analogues with DNA is being actively pursued [1-14].
Chemotherapeutic efficiency as well as cardiotoxicity of anthracycline drugs are associated with electron transfer processes, which show a very good correlation with the redox behavior of the molecules [15-18]. Owing to oneelectron reduction, the quinone moiety in these drugs is converted to semiquinone playing a major role in determining chemotherapeutic efficiency and toxicity in cellular systems $[19,20]$. Analogues of anthracyclines, the hydroxy9,10-anthraquinones and their complexes, were reported to be suitable radiosensitizers [21-23], a phenomenon, also linked to electron transfer processes.

In order to develop cheap but efficient substitutes of anthracycline drugs, different analogues are being tried clinically $[2,24-28]$, and efforts are on going to modify the quinone moiety. One route to such modification has been through complex formation using metal ions that 
reduce formation of superoxide, generating less cardiotoxic yet active anthracyclines $[29,30]$. Several metal complexes of anthracyclines were tried for treating various forms of human cancer $[29,30]$. Studies on the decrease in the formation of superoxide was done by forming metal complexes of 1,2-dihydroxy-9,10-anthraquinone, an analogue of anthracycline drugs [21, 31]. There is, however, a lack of research on the electrochemical behavior of metal-anthracycline complexes to understand whether the biochemical properties of these metal complexes are improved in comparison to the parent drug molecule. Through a recent investigation [32] on a $\mathrm{Cu}(\mathrm{II})$-complex of sodium 1,4-dihydroxy-9,10anthraquinone-2-sulphonate $\left(\mathrm{NaLH}_{2}\right)$, we showed that the electrochemical behavior of $\mathrm{NaLH}_{2}$ is significantly modified in the metal complex. Our recent results [33-35] in aqueous and nonaqueous solvent and a very recent review on the electrochemistry of quinone systems [35] suggest that $\mathrm{NaLH}_{2}$ and other hydroxy-9,10-anthraquinones exhibit electrochemical behavior similar to anthracycline drugs.

In recent studies [32, 34-37], we were successful in showing that 1,4-dihydroxy-9,10-anthraquinone, 1,2,4trihydroxy-9,10-anthraquinone, $\mathrm{NaLH}_{2}$ and its $\mathrm{Cu}(\mathrm{II}) \mathrm{com}$ plex interact with calf thymus DNA (CT DNA), and that the binding parameters evaluated [32] were close to those reported for the anthracycline drugs [38]. Encouraged by these findings, we decided to extend the study to an $\mathrm{Ni}(\mathrm{II})-\mathrm{NaLH}_{2}$ complex because of a difference in electronic constitution with $\mathrm{Cu}(\mathrm{II})$. Using a metal ion whose chemistry differs from $\mathrm{Cu}(\mathrm{II})$ enabled us to understand the role played by metal ions during the process of interaction of the complexes of hydroxy-9,10-anthraquinones to CT DNA. Further, this study was carried out to see whether metal complex formation could increase the intrinsic binding constant value of sodium 1,4-dihydroxy-9,10-anthraquinone-2-sulphonate $\left(\mathrm{NaLH}_{2}\right)$ to calf thymus DNA. Ni(II) being a biologically friendly metal ion $[39,40]$ was another reason for our choice.

The cytotoxicity of hydroxy-9,10-anthraquinones and anthracyclines increase with an increase in their singleelectron reduction midpoint potential [41, 42]. A close parallel was found in the reactivity of hydroxy-9,10anthraquinones and anthracyclines with single-electron transferring flavoenzymes ferredoxin: $\mathrm{NADP}^{+}$reductase and NADPH: cytochrome P-450 reductase, and their cytotoxicity [42]. Thus it is important to evaluate the electrochemical parameters for this class of molecules to correlate their cytotoxicity with electrochemical behavior. In previous studies from our group we observed that metal complex formation reduces the toxicity of hydroxy-9,10-anthraquinones [21,31] which means that our present $\mathrm{Ni}$ (II) complex would be less toxic than $\mathrm{NaLH}_{2}$.

$\mathrm{Ni}(\mathrm{II})$ forms $1: 2$ metal complex with $\mathrm{NaLH}_{2}$. The effective stability constant of the complex was found to be $2.46 \times 10^{13}[43]$. The complex $\left[\mathrm{Ni}(\mathrm{NaLH})_{2} \mathrm{Cl}_{2}\right] \cdot 2 \mathrm{H}_{2} \mathrm{O}$ [43] was characterized by quantitative analysis of the metal ion, elemental analysis, IR, mass spectra, TGA, and magnetic studies. The proposed structure of the complex has been shown in Scheme 1. To find out the crystal structure of the $\mathrm{Ni}(\mathrm{II})$ complex several methods to grow a single crystal were carried out extensively using different solvent compositions and techniques. The method used in the reported crystal structure of terbium(III) complex of sodium 1,4-dihydroxy9,10-anthraquinone-2-sulphonate [44] was also followed. However, all attempts failed to obtain a single crystal for the said species. This is in accordance with the nature of anthracyclines and anthraquinones as there are not many reports of their forming single crystals with metal ions $[32,44]$. The planarity of the anthraquinone moiety may be responsible for this, why such compounds do not easily form crystals that can be collected and mounted on a X-ray diffractometer for systematic analysis. Therefore, a crystal structure of our $\mathrm{Ni}$ (II) complex with sodium 1,4-dihydroxy9,10-anthraquinone-2-sulphonate was not achieved. This being a disadvantage as far as characterization of the complex is concerned we were cautious in the other experiments we performed to determine the structure of the complex such as elemental analysis, IR spectroscopy and mass spectra. These were performed several times from different crops of prepared material and the results obtained were reproducible. In this study, interaction with CT DNA was monitored by cyclic voltammetry $(\mathrm{CV})$ and the binding parameters evaluated using non-linear curve fit analysis, for the first time by monitoring the cathodic peak current of the compound.

\section{Experimental}

2.1. Reagents and Chemicals. Sodium 1,4-dihydroxy-9,10anthraquinone-2-sulphonate was prepared by sulphonation of 1,4-dihydroxy-9,10-anthraquinone (Sigma-Aldrich) and was characterized by our methods $[32,34]$. The $\mathrm{Ni}(\mathrm{II})$ complex, $\mathrm{Na}_{2}\left[\mathrm{Ni}(\mathrm{NaLH})_{2} \mathrm{Cl}_{2}\right] \cdot 2 \mathrm{H}_{2} \mathrm{O}$ was prepared and characterized as described earlier [43]. The quinone moiety being sensitive to light solutions were prepared just before the experiment and kept in dark. Sodium chloride (AR grade) obtained from Merck, Germany, was used as supporting electrolyte in aqueous media. Since in physiological solution the ionic strength is mainly maintained by $\mathrm{NaCl}$, therefore, in our studies we used $\mathrm{NaCl}$ inspite of other electrolytes. Analytical grade Hepes buffer (N-2Hydroxyethylpiperazine-N-2-ethane-Sulphonic acid [45]), $\left(0.02 \mathrm{~mol} \mathrm{dm}^{-3}\right)$; (Specrochem Pvt. Ltd., India) was used to maintain $\mathrm{pH}$. Calf thymus DNA (CT DNA) was purchased from Sisco Research Laboratories Pvt. Ltd., India, and after dissolution in buffer purity was checked from the absorbance ratio $A_{260} / A_{280}$. For all the solutions the absorption ratio was in the range $1.8<\mathrm{A}_{260} / \mathrm{A}_{280}<1.9$. Therefore, no further deproteinization of the DNA was required. Concentration of DNA in terms of nucleotide was determined taking $\varepsilon_{260}=$ $6600 \mathrm{~mol}^{-1} \mathrm{dm}^{3} \mathrm{~cm}^{-1}$ per base for calf thymus DNA. In all the experiments, DNA concentration was expressed in terms of base. All solutions were prepared in triple distilled water.

2.2. Apparatus. Cyclic voltammetry experiments were carried out using conventional three-electrode system at $25^{\circ} \mathrm{C}$. The temperature was maintained using a circulating water bath. A glassy carbon electrode of surface area $0.1256 \mathrm{~cm}^{2}$ served as the working electrode, a platinum wire acted as the counter electrode while $\mathrm{Ag} / \mathrm{AgCl}$, satd. $\mathrm{KCl}$ was the reference electrode. Experiments were done using $E G \& G$ Potentiostat 


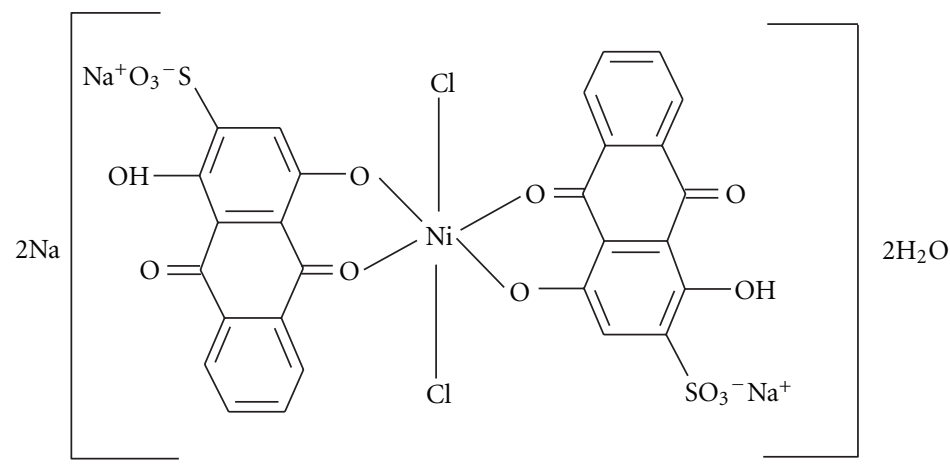

Scheme 1: Proposed structure of $\mathrm{Na}_{2}\left[\mathrm{Ni}(\mathrm{NaLH})_{2} \mathrm{Cl}_{2}\right] \cdot 2 \mathrm{H}_{2} \mathrm{O}$.

Model 263A (Princeton Applied Research, USA). All experimental solutions were degassed for $30 \mathrm{~min}$ with high-purity argon gas, before an electrochemical experiment. Microprocessor pH/ION Meter (pMX 3000) (WTW, Weilheim, Germany) was used for checking $\mathrm{pH}$-values of solutions. The absorbance of DNA solution was measured using a UNICAM spectrophotometer, model UV 500 (UNICAM Ltd., Cambridge). A pair of $10 \times 10 \mathrm{~mm}$ path length quartz cuvette was used for absorption experiments. Fluorescence spectroscopic measurements were carried out using a fluorimeter, model HITACHI S-7000 (HITACHI, Japan).

2.3. Preparation of Experimental Solutions. The uncertainty in weighing of the solid $\mathrm{Na}_{2}\left[\mathrm{Ni}(\mathrm{NaLH})_{2} \mathrm{Cl}_{2}\right] \cdot 2 \mathrm{H}_{2} \mathrm{O}$ was less than $0.3 \%$ indicating that the error in weighing is negligible or within acceptable limits. In the DNA interaction study, the concentration of $\mathrm{Na}_{2}\left[\mathrm{Ni}(\mathrm{NaLH})_{2} \mathrm{Cl}_{2}\right] \cdot 2 \mathrm{H}_{2} \mathrm{O}$ was $23.81 \mu \mathrm{M}$, that is, $23.81 \times 10^{-6} \mathrm{~mol} \mathrm{dm}^{-3}$. The solution was prepared by an exact dilution of a stock aqueous solution $\left(2 \times 10^{-4} \mathrm{~mol} \mathrm{dm}^{-3}\right)$ with an aqueous solution containing $0.500 \mathrm{~mol} \mathrm{dm}^{-3} \mathrm{NaCl}$ and $10 \times 10^{-3} \mathrm{~mol} \mathrm{dm}^{-3}$ Hepes buffer ( $\mathrm{pH}$ 7.4) using a calibrated micropipette (Pipetman-M23866E, Gilson, France). To check concentrations of $\mathrm{Na}_{2}\left[\mathrm{Ni}(\mathrm{NaLH})_{2} \mathrm{Cl}_{2}\right] \cdot 2 \mathrm{H}_{2} \mathrm{O}$ in the experimental solutions, a calibration experiment (Lambert Beer's Law) was done by measuring absorbance of different solutions of $\mathrm{Na}_{2}\left[\mathrm{Ni}(\mathrm{NaLH})_{2} \mathrm{Cl}_{2}\right] \cdot 2 \mathrm{H}_{2} \mathrm{O}$ of known strength at $465 \mathrm{~nm}$, using which the concentration of $\mathrm{Na}_{2}\left[\mathrm{Ni}(\mathrm{NaLH})_{2} \mathrm{Cl}_{2}\right] \cdot 2 \mathrm{H}_{2} \mathrm{O}$ could be checked during the experiments. A $6.00 \times$ $10^{-3} \mathrm{~mol} \mathrm{dm}^{-3}$ aqueous solution of CT DNA (stock solution) was prepared and this was added quantitatively using a calibrated micropipette in each titration.

2.4. Methods. The electrochemical behavior of the Ni(II)$\mathrm{NaLH}_{2}$ complex was studied in aqueous solution using cyclic voltammetry. Cyclic voltammetry was also carried out to study the interaction of the compound with calf thymus DNA. The non linear curve fit analysis usually applied in the spectrophotometric and fluorimetric studies was used first time in cyclic voltammetry studies to determine the binding parameters. The intercalation of $\mathrm{Ni}$ (II)- $\mathrm{NaLH}_{2}$ complex into DNA base pairs was established by competitive binding study using ethidium bromide in fluorescence spectroscopy.

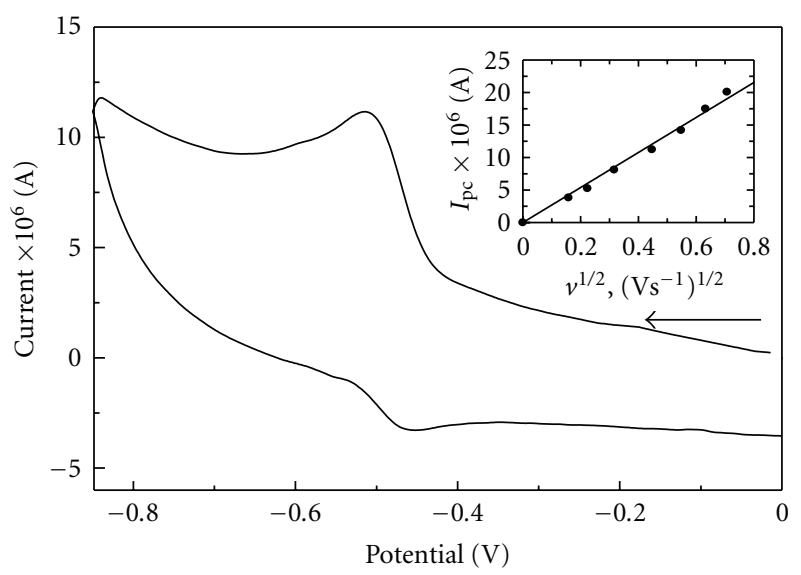

Figure 1: Cyclic voltammogram of $23.806 \times 10^{-6} \mathrm{~mol} \mathrm{dm}^{-3}$ $\mathrm{Na}_{2}\left[\mathrm{Ni}(\mathrm{NaLH})_{2} \mathrm{Cl}_{2}\right] \cdot 2 \mathrm{H}_{2} \mathrm{O}$ in Hepes buffer at $\mathrm{pH} 7.4$ containing $0.500 \mathrm{~mol} \mathrm{dm}^{-3} \mathrm{NaCl}$. Electrode: glassy carbon of surface area $0.1256 \mathrm{~cm}^{2}$; scan rate $=0.200 \mathrm{~V} / \mathrm{s}, 25^{\circ} \mathrm{C}$. Inset: typical plot of cathodic peak current versus square root of scan rate for the oneelectron reduction of $\mathrm{Na}_{2}\left[\mathrm{Ni}(\mathrm{NaLH})_{2} \mathrm{Cl}_{2}\right] \cdot 2 \mathrm{H}_{2} \mathrm{O}$ in Hepes buffer at $\mathrm{pH} 7.4$.

\section{Results and Discussion}

3.1. Electrochemical Reduction of $\mathrm{Na}_{2}\left[\mathrm{Ni}(\mathrm{NaLH})_{2} \mathrm{Cl}_{2}\right] \cdot 2 \mathrm{H}_{2} \mathrm{O}$ in Aqueous Solution. In Hepes buffer [45], pH 7.4 containing $0.500 \mathrm{~mol} \mathrm{dm}^{-3} \mathrm{NaCl}, \mathrm{Na}_{2}\left[\mathrm{Ni}(\mathrm{NaLH})_{2} \mathrm{Cl}_{2}\right] \cdot 2 \mathrm{H}_{2} \mathrm{O}(23.81 \times$ $10^{-6} \mathrm{~mol} \mathrm{dm}^{-3}$ ) undergoes one-electron reversible reduction generating a cathodic peak at $-(515 \pm 5) \mathrm{mV}$ (versus $\mathrm{Ag} / \mathrm{AgCl}$, satd. $\mathrm{KCl}$ ) with the corresponding anodic peak at $-(462 \pm 5) \mathrm{mV}$ (versus $\mathrm{Ag} / \mathrm{AgCl}$, satd. $\mathrm{KCl}$ ); (Figure 1). The formal reduction potential $\left(E_{1 / 2}\right)$ was $-(489 \pm 5) \mathrm{mV}$ (versus $\mathrm{Ag} / \mathrm{AgCl}$, satd. $\mathrm{KCl}$ ). Previous study showed that the formal reduction potential for the one-electron reduction of sodium 1,4-dihdroxy-9,10-anthraquinone-2-sulphonate is $-270 \mathrm{mV}$ (versus NHE) [46], that is, $-469 \mathrm{mV}$ (versus $\mathrm{Ag} / \mathrm{AgCl}$, satd. $\mathrm{KCl})$ which is nearer to the formal reduction potential of the complex $\mathrm{Na}_{2}\left[\mathrm{Ni}(\mathrm{NaLH})_{2} \mathrm{Cl}_{2}\right] \cdot 2 \mathrm{H}_{2} \mathrm{O}-(489 \pm 5) \mathrm{mV}$ (versus $\mathrm{Ag} / \mathrm{AgCl}$, satd. $\mathrm{KCl}$ ) obtained in this study. The slight deviation in the value of the formal reduction potential of the $\mathrm{Ni}(\mathrm{II})$ complex is due to a different environment 
for the quinone in the metal complex. This indicates that in the present study the electron does not reduce $\mathrm{Ni}(\mathrm{II})$ in the complex to $\mathrm{Ni}(\mathrm{I})$; rather it reduces the free quinone site in the complex. Under the similar experimental conditions the cyclic voltammetry of $23.81 \times 10^{-6} \mathrm{~mol} \mathrm{dm}^{-3}$ $\mathrm{NiCl}_{2}$ (same concentration as that in the complex) did not exhibit any reduction or oxidation peak in the same potential range clearly indicating that $\mathrm{Ni}$ (II) present in the complex was not responsible for the peak. Thus it is evident from this study that the reduction and oxidation peaks of $\mathrm{Na}_{2}\left[\mathrm{Ni}(\mathrm{NaLH})_{2} \mathrm{Cl}_{2}\right] \cdot 2 \mathrm{H}_{2} \mathrm{O}$ are solely due to the quinone and not due to the $\mathrm{Ni}$ (II) present in the complex.

In aqueous media, except for the cathodic peak at $-(515 \pm 5) \mathrm{mV}$ (versus $\mathrm{Ag} / \mathrm{AgCl}$, satd. $\mathrm{KCl}$ ) no other cathodic peak was observed at more negative potential. It was found that the ratio of the anodic to cathodic peak current $\left(I_{\mathrm{pa}} / I_{\mathrm{pc}}\right)$ is less than unity in lower scan rate while at higher scan rate it is almost unity, indicating that in aqueous solution reduction of the compound at lower scan rates is quasireversible at physiological $\mathrm{pH}$. The cathodic peak current $\left(I_{\mathrm{pc}}\right)$ for the reduction has a linear relationship with square root of scan rate that passes through the origin (inset of Figure 1) following equation-(1) [47] indicating that the reduction is diffusion controlled and that there is no adsorption on to the electrode surface. Therefore, it could be concluded that the reduction peak current $\left(I_{\mathrm{pc}}\right)$ has a linear relationship with concentration;

$$
I_{\mathrm{pc}}=0.4463\left(\frac{F^{3}}{R T}\right)^{1 / 2} n^{3 / 2} A_{0} D_{0}^{1 / 2} C_{0} v^{1 / 2},
$$

where, $I_{\mathrm{pc}}, n, A_{0}, D_{0}, C_{0}$, and $v$ refer to the cathodic peak current (A), number of electrons involved in the reduction, area of the electrode $\left(\mathrm{cm}^{2}\right)$, diffusion coefficient $\left(\mathrm{cm}^{2} \mathrm{~s}^{-1}\right)$, concentration $\left(\mathrm{mol} \mathrm{cm}^{-3}\right)$, and scan rate $\left(\mathrm{Vs}^{-1}\right)$, respectively. In our experiments temperature was maintained at $25^{\circ} \mathrm{C}$ $(298 \mathrm{~K})$ and therefore one gets the value of $0.4463\left(F^{3} / R T\right)^{1 / 2}$ as $2.687 \times 10^{5} \mathrm{As}\left(\mathrm{mol} \mathrm{V}^{1 / 2}\right)^{-1}$. Using (1) the diffusion coefficient of $\mathrm{Na}_{2}\left[\mathrm{Ni}(\mathrm{NaLH})_{2} \mathrm{Cl}_{2}\right] \cdot 2 \mathrm{H}_{2} \mathrm{O}$ was evaluated to be $(1.15 \pm 0.10) \times 10^{-5} \mathrm{~cm}^{2} \mathrm{~s}^{-1}$.

Our recent studies $[33,34]$ showed that sodium 1,4-dihydroxy-9,10-anthraquinone-2-sulphonate undergoes diffusion-controlled two-electron reduction in aqueous media at any $\mathrm{pH}$. The present study showed upon complex formation with metal ions, the electrochemical behavior of sodium 1,4-dihydroxy-9,10-anthraquinone-2-sulphonate changes significantly indicating an improvement in biochemical behavior. This could lead to a lesser generation of semiquinone, responsible for cardiotoxicity in anthracycline drugs [19, 20].

3.2. Interaction of $\mathrm{Na}_{2}\left[\mathrm{Ni}(\mathrm{NaLH})_{2} \mathrm{Cl}_{2}\right] \cdot 2 \mathrm{H}_{2} \mathrm{O}$ with CT DNA. Interaction of $\mathrm{Na}_{2}\left[\mathrm{Ni}(\mathrm{NaLH})_{2} \mathrm{Cl}_{2}\right] \cdot 2 \mathrm{H}_{2} \mathrm{O}$ with CT DNA was studied using cyclic voltammetry in aqueous buffer at physiological pH (7.4) containing $0.500 \mathrm{~mol} \mathrm{dm}^{-3} \mathrm{NaCl}$.

Since in aqueous solution the $\mathrm{Ni}$ (II) complex has negative charge on it and DNA being a negatively charged polymer there should be a repulsion in between the two. A high concentration of $\mathrm{NaCl}$ was used to suppress

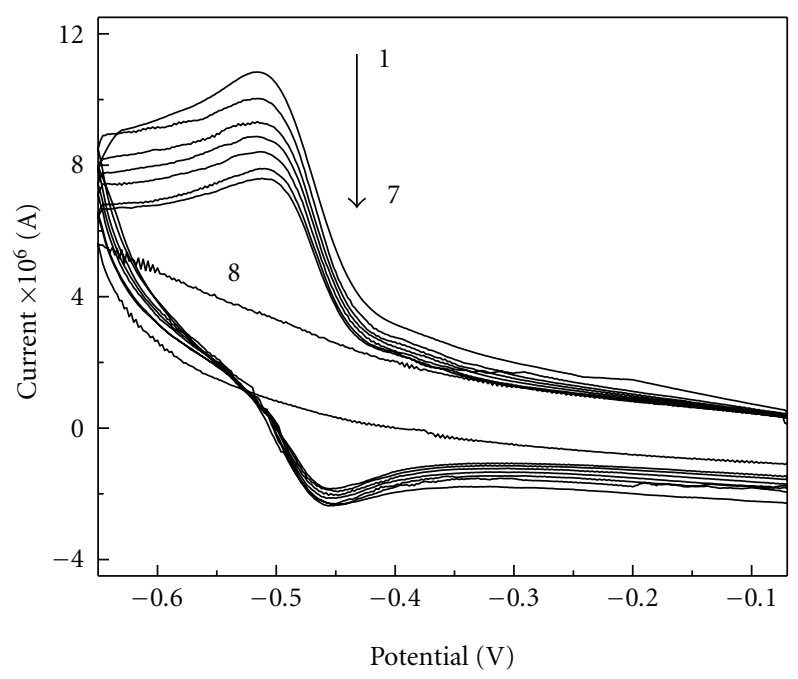

Figure 2: Cyclic voltammogram of $23.806 \times 10^{-6} \mathrm{~mol} \mathrm{dm}^{-3}$ $\mathrm{Na}_{2}\left[\mathrm{Ni}(\mathrm{NaLH})_{2} \mathrm{Cl}_{2}\right] \cdot 2 \mathrm{H}_{2} \mathrm{O}$ in absence (1) and presence of different CT DNA concentrations $\left(\mathrm{mol} \mathrm{dm}^{-3}\right)$ : $98.3 \times 10^{-6}(2), 194.78 \times 10^{-6}$ (3), $336.13 \times 10^{-6}(4), 518.65 \times 10^{-6}(5), 694.67 \times 10^{-6}(6), 906.07 \times$ $10^{-6}(7)$; cyclic voltammogram of $289.44 \times 10^{-6} \mathrm{~mol} \mathrm{dm}{ }^{-3}$ CT DNA (8); $\mathrm{pH}=7.4,[\mathrm{NaCl}]=0.500 \mathrm{~mol} \mathrm{dm}{ }^{-3}$, scan rate $0.200 \mathrm{~V} / \mathrm{s}, 25^{\circ} \mathrm{C}$.

the negative charge on the $\mathrm{Ni}$ (II) complex and negative charge on DNA. Under the experimental conditions, the compound shows a cathodic peak at $-(515 \pm 5) \mathrm{mV}$ (versus $\mathrm{Ag} / \mathrm{AgCl}$, satd. $\mathrm{KCl}$ ); (curve-1, Figure 2). Separate solutions were made containing a constant concentration $\left(23.81 \times 10^{-6}\right.$ mol $\mathrm{dm}^{-3}$ ) of $\mathrm{Na}_{2}\left[\mathrm{Ni}(\mathrm{NaLH})_{2} \mathrm{Cl}_{2}\right] \cdot 2 \mathrm{H}_{2} \mathrm{O}$ and different concentrations of CT DNA. Cyclic voltammetry of each solution was carried out and the change in cathodic peak current at $-515 \mathrm{mV}$ (versus $\mathrm{Ag} / \mathrm{AgCl}$, satd. $\mathrm{KCl}$ ) was used to construct binding isotherms. The cyclic voltammogram of the compound in the absence and presence of different amounts of CT DNA are shown in Figure 2. Under the same experimental conditions cyclic voltammetry experiments with pure DNA (curve 8 of Figure 2) show that there is no cathodic or anodic peak, clearly indicating that pure DNA is electrochemically inactive in the potential range 0.0 to $-0.65 \mathrm{~V}$ on a glassy carbon electrode. Therefore, the cathodic peak current is exclusively due to the $\mathrm{Ni}$ (II) complex which gradually decreased with a positive shift $(8 \mathrm{mV})$ with increasing amounts of CT DNA. The change in cathodic peak current $\left(I_{\mathrm{pc}}\right)$ at $-515 \mathrm{mV}$ (versus $\mathrm{Ag} / \mathrm{AgCl}$, satd. $\mathrm{KCl}$ ) of $\mathrm{Na}_{2}\left[\mathrm{Ni}(\mathrm{NaLH})_{2} \mathrm{Cl}_{2}\right] \cdot 2 \mathrm{H}_{2} \mathrm{O}$ in presence of different CT DNA concentration is shown in Figure 3. At the high concentration of $\mathrm{NaCl}$ used $\left(0.500 \mathrm{~mol} \mathrm{dm}^{-3}\right)$ charge on phosphate groups of DNA and the sulphonate oxygen of $\mathrm{NaLH}_{2}$ in the $\mathrm{Ni}$ (II) complex are suppressed [48]. As a result, electrostatic interaction between the $\mathrm{Ni}$ (II) complex and DNA would be almost negligible, suggesting intercalation as the main and dominating mode of interaction [48]. In an earlier pioneering study on metal complex-DNA interaction Bard et al. [49] reported a positive shift in peak potential for intercalators in the process of binding via hydrophobic interactions (intercalation) and said electrostatic interactions 


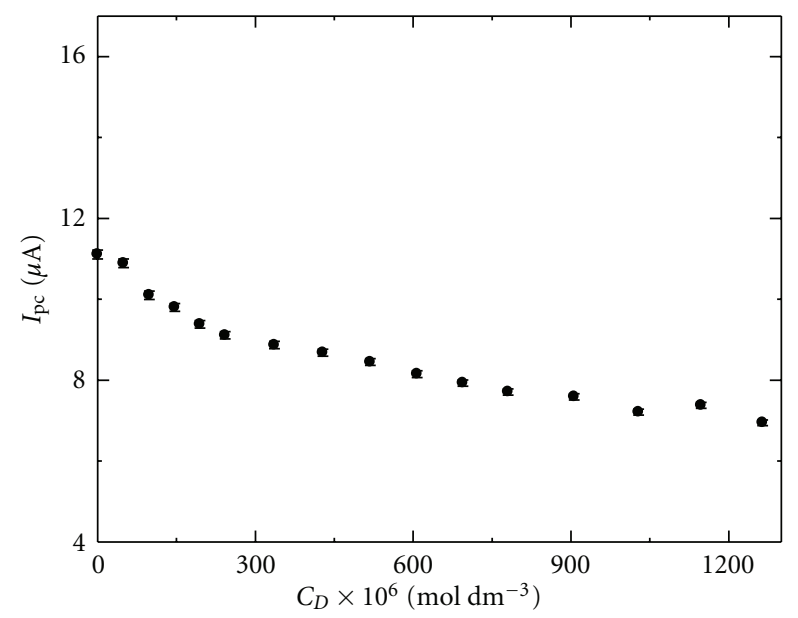

Figure 3: Plot of cathodic peak current $\left(I_{\mathrm{p}}\right)$ of $23.806 \times$ $10^{-6} \mathrm{~mol} \mathrm{dm}^{-3} \mathrm{Na}_{2}\left[\mathrm{Ni}(\mathrm{NaLH})_{2} \mathrm{Cl}_{2}\right] \cdot 2 \mathrm{H}_{2} \mathrm{O}$ in presence of different total CT DNA concentrations, $C_{D}\left(\mathrm{~mol} \mathrm{dm}^{-3}\right)=0,49.38 \times 10^{-6}$; $98.30 \times 10^{-6} ; 146.78 \times 10^{-6} ; 194.78 \times 10^{-6} ; 242.33 \times 10^{-6} ; 336.13 \times$ $10^{-6} ; 428.25 \times 10^{-6} ; 518.65 \times 10^{-6} ; 607.45 \times 10^{-6} ; 694.67 \times 10^{-6}$; $780.35 \times 10^{-6} ; 906.07 \times 10^{-6} ; 1028.58 \times 10^{-6} ; 1147.57 \times 10^{-6}$; $1264.35 \times 10^{-6} .[\mathrm{NaCl}]=0.500 \mathrm{~mol} \mathrm{dm}{ }^{-3}, \mathrm{pH}=7.4,25^{\circ} \mathrm{C}$.

(groove binding) lead to a negative shift of peak potential. In our case upon increasing DNA concentration the cathodic peak decreased in current with a positive shift of about $8 \mathrm{mV}$. Comparing our results with those of Bard et al. [49] we could conclude that the $\mathrm{Ni}$ (II) complex intercalates into DNA base pairs (Scheme 2).

Mode of binding was further established by carrying out competitive binding study using an established DNA intercalator ethidium bromide (EB) [50] and monitoring change in fluorescence under similar conditions of $\mathrm{pH}$, ionic strength, and temperature. A solution of EB shows a strong absorption band with $\lambda_{\max }$ at $470 \mathrm{~nm}$ which upon interaction with DNA shifts to $510 \mathrm{~nm}$. When the DNAEB adduct was excited at $510 \mathrm{~nm}$ fluorescence emission maxima was observed at $590 \mathrm{~nm}$. A mixture containing $200 \times 10^{-6} \mathrm{~mol} \mathrm{dm}^{-3}$ CT DNA with saturating EB $(4000 \times$ $10^{-6} \mathrm{~mol} \mathrm{dm}^{-3}$ ) was incubated for one hour and fluorescence was recorded (Figure 4(a)). To this mixture the complex $\mathrm{Na}_{2}\left[\mathrm{Ni}(\mathrm{NaLH})_{2} \mathrm{Cl}_{2}\right] \cdot 2 \mathrm{H}_{2} \mathrm{O}$ was added and fluorescence of the resultant mixture was taken at different time intervals ranging from incubation time $t=0$ (i.e., taken immediately after adding $\mathrm{Ni}(\mathrm{II})$ complex) to $t=30 \mathrm{~min}$ (Figure 4(a)). It is evident from the figure that addition of the $\mathrm{Ni}(\mathrm{II})$ complex causes a decrease in fluorescence intensity on increasing incubation time. As EB is an intercalator and since fluorescence occurs due to intercalation, a decrease in fluorescence upon addition of $\mathrm{Na}_{2}\left[\mathrm{Ni}(\mathrm{NaLH})_{2} \mathrm{Cl}_{2}\right] \cdot 2 \mathrm{H}_{2} \mathrm{O}$ clearly indicates that the complex intercalates between the strands of DNA for it replaces EB leading to loss in fluorescence. Though EB is amuch stronger intercalator to DNA (having very high binding constant) in comparison to the $\mathrm{Ni}(\mathrm{II})$ complex but there is some competition between $\mathrm{EB}$ and $\mathrm{Na}_{2}\left[\mathrm{Ni}(\mathrm{NaLH})_{2} \mathrm{Cl}_{2}\right] \cdot 2 \mathrm{H}_{2} \mathrm{O}$ for binding to DNA that could be explained considering the equilibrium for binding of EB with ct DNA and that of $\mathrm{Na}_{2}\left[\mathrm{Ni}(\mathrm{NaLH})_{2} \mathrm{Cl}_{2}\right] \cdot 2 \mathrm{H}_{2} \mathrm{O}$ with ct DNA. Thus there is a replacement of EB from the already formed EB-DNA adduct by the Ni(II) complex according to the principle of chemical equilibrium.

It needs to be mentioned that the decrease in the cathodic peak current upon addition of increasing amount of DNA is due to interaction of the $\mathrm{Ni}(\mathrm{II})$-complex with DNA and not due to any blockage of the electrode surface by an adsorbed layer of DNA. To verify this we carried out cyclic voltammetry experiment of potassium ferricyanide in absence and presence of different amount of ct DNA under similar experimental conditions. It was observed that although concentration of ct DNA was increased, the cathodic peak current of potassium ferricyanide did not decrease, indicating that there was no adsorption of DNA onto the glassy carbon electrode surface. In a previous study involving metal complex-DNA interaction Bard et al. [49] established that a decrease in current in CV experiments was due to diffusion of the metal complex bound to the large, slowly diffusing DNA molecule. Enhanced viscosity of DNA solutions apparently has only a small effect on diffusion, and there is no significant obstruction of the glassy carbon surface via adsorption of DNA even at very high concentration of DNA $\left(\sim 5 \times 10^{-3} \mathrm{~mol} \mathrm{dm}^{-3}\right)$ [49]. In our study, since we used $\sim 1.3 \times 10^{-3} \mathrm{~mol} \mathrm{dm}^{-3}$ DNA concentration as maximum reasons obvious there is very little chance [49] of adsorption of DNA on to the glassy carbon electrode surface. In another DNA interaction study, Radi et al. [51] carried out a similar ferricyanide experiment to establish that the cyclic voltammetric behavior of their studied compound was not affected by the addition of a very large excess of DNA and decrease in peak current of the compound was due to interaction of the compound with DNA.

Results of the DNA titration using cyclic voltammetry were analyzed by the method of nonlinear fitting. To do so, the following compound-DNA equilibrium was considered $[32,34-37,52-55]$ :

$$
\begin{gathered}
L+D \rightleftharpoons \mathrm{LD} \\
K_{d}=\frac{\lfloor L\rfloor[D]}{[\mathrm{LD}]}=\frac{\left\{\left[L_{0}\right]-[\mathrm{LD}]\right\}\left\{\left[D_{0}\right]-[\mathrm{LD}]\right\}}{\mathrm{LD}},
\end{gathered}
$$

where $L$ represents $\mathrm{Na}_{2}\left[\mathrm{Ni}(\mathrm{NaLH})_{2} \mathrm{Cl}_{2}\right] \cdot 2 \mathrm{H}_{2} \mathrm{O}, D$ represents CT DNA and LD, represents the DNA $\cdot \mathrm{Na}_{2}\left[\mathrm{Ni}(\mathrm{NaLH})_{2} \mathrm{Cl}_{2}\right]$. $2 \mathrm{H}_{2} \mathrm{O}$ adduct. The dissociation constant $\left(K_{d}\right)=1 / K$; $\mathrm{K}$ being the apparent binding constant of the compound to DNA. $\left[L_{0}\right]=$ initial concentration of $\mathrm{Na}_{2}\left[\mathrm{Ni}(\mathrm{NaLH})_{2} \mathrm{Cl}_{2}\right]$. $2 \mathrm{H}_{2} \mathrm{O}=\left[\mathrm{Na}_{2}\left[\mathrm{Ni}(\mathrm{NaLH})_{2} \mathrm{Cl}_{2}\right] \cdot 2 \mathrm{H}_{2} \mathrm{O}\right]_{0}=23.81 \times 10^{-6} \mathrm{~mol}$ $\mathrm{dm}^{-3}$ (which was kept constant during the titration experiment $) .\left[D_{0}\right]=[\mathrm{DNA}]=$ concentration of DNA added to an aliquot. If $C_{0}$ be the initial concentration of $\mathrm{Na}_{2}\left[\mathrm{Ni}(\mathrm{NaLH})_{2} \mathrm{Cl}_{2}\right] \cdot 2 \mathrm{H}_{2} \mathrm{O}$, that is, $C_{0}=\left[L_{0}\right]=$ $\left[\mathrm{Na}_{2}\left[\mathrm{Ni}(\mathrm{NaLH})_{2} \mathrm{Cl}_{2}\right] \cdot 2 \mathrm{H}_{2} \mathrm{O}\right]_{0}$ and $C_{D}=\left[D_{0}\right]=[\mathrm{DNA}]=$ the concentration of DNA added to an aliquot then:

$$
K_{d}=\frac{\left\{C_{0}-\lfloor\mathrm{LD}\rfloor\right\}\left\{C_{D}-\lfloor\mathrm{LD}\rfloor\right\}}{[\mathrm{LD}]} .
$$




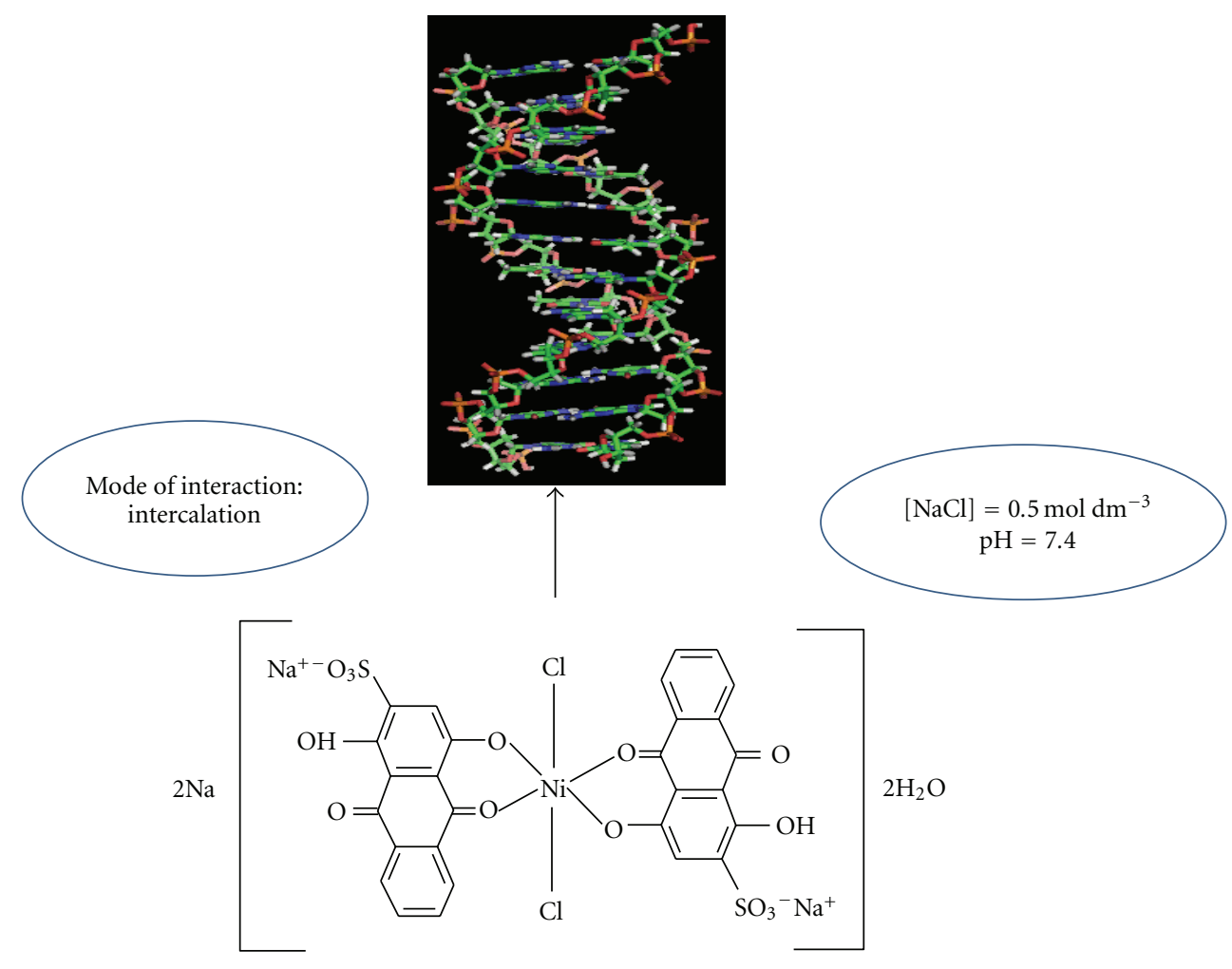

Scheme 2: Proposed scheme for the intercalation of $\mathrm{Na}_{2}\left[\mathrm{Ni}(\mathrm{NaLH})_{2} \mathrm{Cl}_{2}\right] \cdot 2 \mathrm{H}_{2} \mathrm{O}$ into DNA base pairs.

As discussed earlier, reduction of the compound in aqueous buffer is purely diffusion controlled and that there is no adsorption on to the electrode surface. As there is no interference from the DNA bound form the cathodic peak current $\left(I_{\mathrm{pc}}\right)$ is therefore linearly proportional to the concentration of $\mathrm{Na}_{2}\left[\mathrm{Ni}(\mathrm{NaLH})_{2} \mathrm{Cl}_{2}\right] \cdot 2 \mathrm{H}_{2} \mathrm{O}$ (1) [40]. Using this linear relationship between cathodic peak current and concentration of the compound and applying the same analogy that one applies for absorption and fluorescence methods [32, 34-37, 52-55] the following parameters can be defined.

$\Delta I=\left(I_{\mathrm{pc}}^{0}-I_{\mathrm{pc}}\right)=$ change in cathodic peak current $\left(I_{\mathrm{pc}}\right)$ of $\mathrm{Na}_{2}\left[\mathrm{Ni}(\mathrm{NaLH})_{2} \mathrm{Cl}_{2}\right] \cdot 2 \mathrm{H}_{2} \mathrm{O}$ at $-515 \mathrm{mV}$ (versus $\mathrm{Ag} / \mathrm{AgCl}$, satd. $\mathrm{KCl}$ ) upon each addition of CT DNA for each point of the titration curve. $I_{\mathrm{pc}}^{0}$ and $I_{\mathrm{pc}}$ are cathodic peak current of $\mathrm{Na}_{2}\left[\mathrm{Ni}(\mathrm{NaLH})_{2} \mathrm{Cl}_{2}\right] \cdot 2 \mathrm{H}_{2} \mathrm{O}$ at $-515 \mathrm{mV}$ (versus $\mathrm{Ag} / \mathrm{AgCl}$, satd. $\mathrm{KCl}$ ) in the absence and presence of different amounts of CT DNA respectively. $\Delta I_{\max }$ is the same parameter when the compound is totally bound to CT DNA. Therefore, $\left(\Delta I / \Delta I_{\max }\right)$ denotes the fraction of $\mathrm{Na}_{2}\left[\mathrm{Ni}(\mathrm{NaLH})_{2} \mathrm{Cl}_{2}\right] \cdot 2 \mathrm{H}_{2} \mathrm{O}$ bound to DNA and one gets, $\left(\Delta I / \Delta I_{\max }\right) C_{0}=[\mathrm{LD}]=[\mathrm{DNA}$. $\left.\mathrm{Na}_{2}\left[\mathrm{Ni}(\mathrm{NaLH})_{2} \mathrm{Cl}_{2}\right] \cdot 2 \mathrm{H}_{2} \mathrm{O}\right]$. At any point of the titration the cathodic peak current is due to the contribution of both the free and the bound forms. $\Delta I$ corresponds to $\left(m c_{f}^{i}-m^{\prime} c_{b}^{i}\right)$ where $c_{b}^{i}$ refers to the concentration of the bound form of $\mathrm{Na}_{2}\left[\mathrm{Ni}(\mathrm{NaLH})_{2} \mathrm{Cl}_{2}\right] \cdot 2 \mathrm{H}_{2} \mathrm{O}, c_{f}^{i}$ being its corresponding concentration in absence of DNA. $m$ is a constant equal to $0.4463\left(F^{3} / R T\right)^{1 / 2} n^{3 / 2} A_{0} D_{0}^{1 / 2} C_{0} v^{1 / 2}$ for the free form of
$\mathrm{Na}_{2}\left[\mathrm{Ni}(\mathrm{NaLH})_{2} \mathrm{Cl}_{2}\right] \cdot 2 \mathrm{H}_{2} \mathrm{O}$, while $m^{\prime}$ is the same constant for the bound form of $\mathrm{Na}_{2}\left[\mathrm{Ni}(\mathrm{NaLH})_{2} \mathrm{Cl}_{2}\right] \cdot 2 \mathrm{H}_{2} \mathrm{O}$ that is, DNA $\cdot \mathrm{Na}_{2}\left[\mathrm{Ni}(\mathrm{NaLH})_{2} \mathrm{Cl}_{2}\right] \cdot 2 \mathrm{H}_{2} \mathrm{O}$. Putting the value of [LD] in (3) one gets,

$$
\begin{aligned}
& K_{d}=\frac{\left[C_{0}-\left(\Delta I / \Delta I_{\max }\right) C_{0}\right]\left[C_{D}-\left(\Delta I / \Delta I_{\max }\right) C_{0}\right]}{\left(\Delta I / \Delta I_{\max }\right) C_{0}}, \\
& C_{0}\left(\frac{\Delta I}{\Delta I_{\max }}\right)^{2}-\left(C_{0}+C_{D}+K_{d}\right)\left(\frac{\Delta I}{\Delta I_{\max }}\right)+C_{D}=0,
\end{aligned}
$$

Determination of $K_{d}$ using (5) requires the value of $\Delta I_{\max }$ which was determined by double reciprocal plot (Figure 4(b)) using (6) [32, 34-37, 52-55]:

$$
\frac{1}{\Delta I}=\frac{1}{\Delta I_{\max }}+\frac{K_{d}}{\Delta I_{\max }\left(C_{D}-C_{0}\right)} .
$$

This double reciprocal plot (Figure 4(b)) was also used to determine the apparent dissociation constant $\left(K_{d}\right)$. The apparent dissociation constant $\left(K_{d}\right)$ was determined using nonlinear curve fit analysis using (5). All experimental points in binding isotherms were fitted by least square analysis. The basic assumption of this study is that the concentration of $\mathrm{Na}_{2}\left[\mathrm{Ni}(\mathrm{NaLH})_{2} \mathrm{Cl}_{2}\right] 2 \mathrm{H}_{2} \mathrm{O}$ was $23.81 \times 10^{-6} \mathrm{~mol} \mathrm{dm}^{-3}$ (which was kept constant all along the titration) and CT DNA concentration was kept 53 -fold greater than that of the compound. 


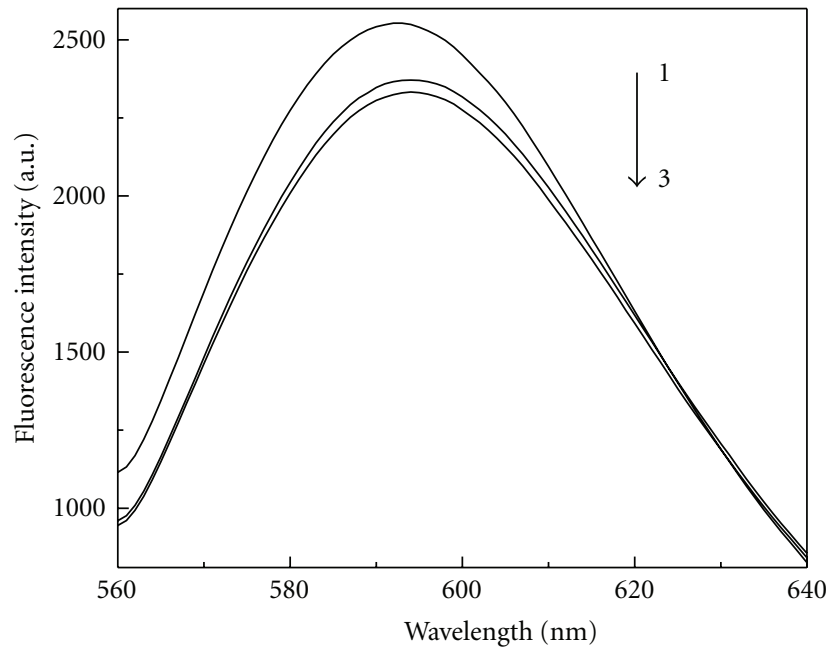

(a)

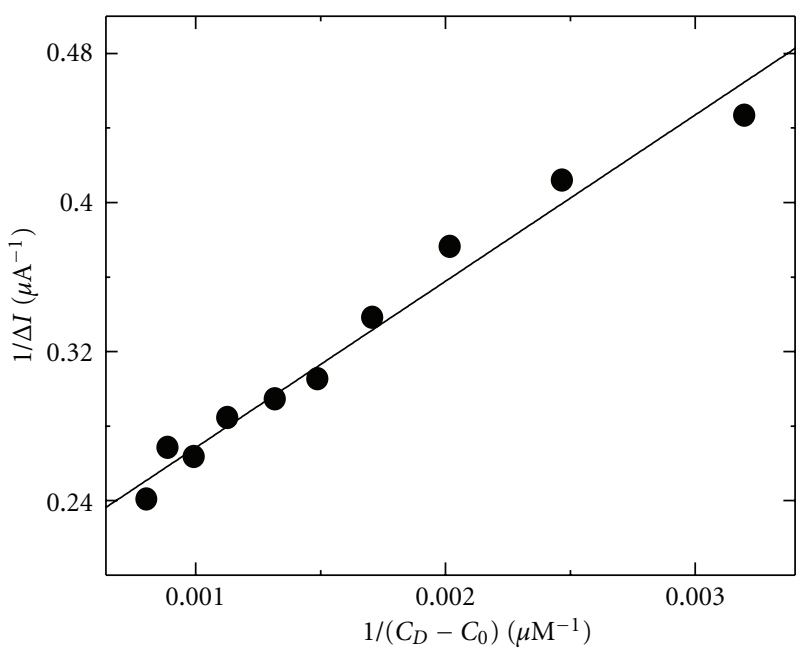

(b)

FIgURE 4: (a) Fluorescence spectra of (1) $200 \times 10^{-6}$ mol dm ${ }^{-3}$ DNA with saturating EB $\left(4000 \times 10^{-6}\right.$ mol dm $\left.^{-3}\right)$ incubated for 1 hour; (2) $200 \times 10^{-6} \mathrm{~mol} \mathrm{dm}^{-3}$ DNA with saturating EB $\left(4000 \times 10^{-6} \mathrm{~mol} \mathrm{dm}^{-3}\right)$ incubated for 1 hour followed by addition of $3 \times 10^{-6} \mathrm{~mol} \mathrm{dm}^{-3}$ $\mathrm{Na}_{2}\left[\mathrm{Ni}(\mathrm{NaLH})_{2} \mathrm{Cl}_{2}\right] \cdot 2 \mathrm{H}_{2} \mathrm{O}$; (3) $200 \times 10^{-6} \mathrm{~mol} \mathrm{dm}^{-3}$ DNA with saturating EB incubated for 1 hour followed by addition of $3 \times 10^{-6} \mathrm{~mol} \mathrm{dm}^{-3}$ $\mathrm{Na}_{2}\left[\mathrm{Ni}(\mathrm{NaLH})_{2} \mathrm{Cl}_{2}\right] \cdot 2 \mathrm{H}_{2} \mathrm{O}$ with incubation time 30 mins. $\mathrm{pH}=7.4,[\mathrm{NaCl}]=0.500 \mathrm{~mol} \mathrm{dm}^{-3}, 25^{\circ} \mathrm{C}$. (b) Typical double reciprocal plot for $\mathrm{Na}_{2}\left[\mathrm{Ni}(\mathrm{NaLH})_{2} \mathrm{Cl}_{2}\right] \cdot 2 \mathrm{H}_{2} \mathrm{O}-\mathrm{CT}$ DNA interaction; $\left[\mathrm{Na}_{2}\left[\mathrm{Ni}(\mathrm{NaLH})_{2} \mathrm{Cl}_{2}\right] \cdot 2 \mathrm{H}_{2} \mathrm{O}\right]=23.81 \times 10^{-6} \mathrm{~mol} \mathrm{dm}^{-3}, \mathrm{pH}=7.4,[\mathrm{NaCl}]=$ $0.500 \mathrm{~mol} \mathrm{dm}^{-3}, 25^{\circ} \mathrm{C}$.

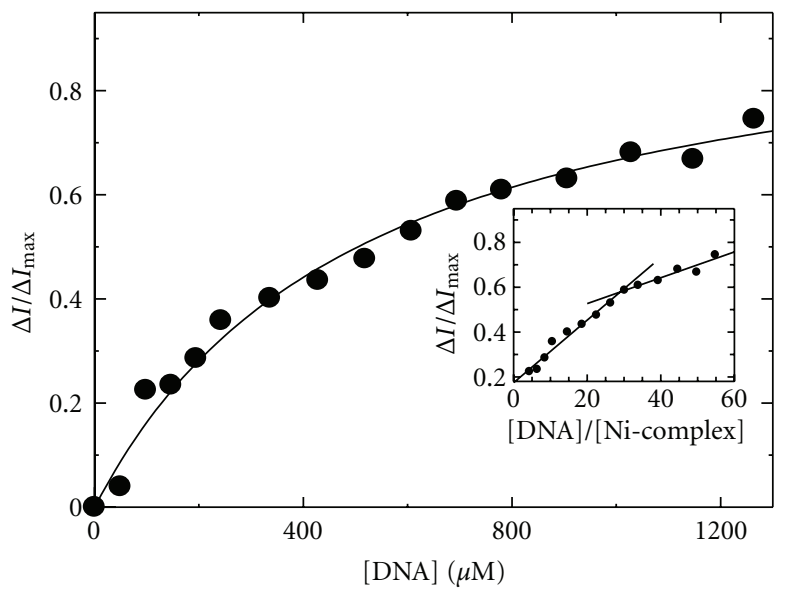

FIgURE 5: Typical binding isotherm of $\mathrm{Na}_{2}\left[\mathrm{Ni}(\mathrm{NaLH})_{2} \mathrm{Cl}_{2}\right] \cdot 2 \mathrm{H}_{2} \mathrm{O}$ and CT DNA and corresponding nonlinear fit using cyclic voltammetry method; $\left[\mathrm{Na}_{2}\left[\mathrm{Ni}(\mathrm{NaLH})_{2} \mathrm{Cl}_{2}\right] \cdot 2 \mathrm{H}_{2} \mathrm{O}\right]=23.81 \times$ $10^{-6} \mathrm{~mol} \mathrm{dm}^{-3}, \mathrm{pH}=7.4,[\mathrm{NaCl}]=0.500 \mathrm{~mol} \mathrm{dm}^{-3}, 25^{\circ} \mathrm{C}$; Inset: typical plot of normalized increase of cathodic peak current as a function of mole-ratio of CT DNA to $\mathrm{Na}_{2}\left[\mathrm{Ni}(\mathrm{NaLH})_{2} \mathrm{Cl}_{2}\right] \cdot 2 \mathrm{H}_{2} \mathrm{O}$.

Binding stoichiometry or the binding site size was determined from the point of intersection of two straight lines obtained from the least square fit plot of normalized increase of $\Delta I / \Delta I_{\max }$ against the ratio of concentration of CT DNA (in base) and the compound [52]. The two straight lines were drawn considering points before and after saturation, respectively [52]. The point of intersection of the two straight lines indicate a ratio of the moles of DNA (in bases) to the mole of the $\mathrm{Ni}$ (II) complex at the point in which the saturatation is just reached, that is, the number of DNA bases bound per molecule of $\mathrm{Na}_{2}\left[\mathrm{Ni}(\mathrm{NaLH})_{2} \mathrm{Cl}_{2}\right] \cdot 2 \mathrm{H}_{2} \mathrm{O}$. Figure 5 shows the binding isotherm of $\mathrm{Na}_{2}\left[\mathrm{Ni}(\mathrm{NaLH})_{2} \mathrm{Cl}_{2}\right] \cdot 2 \mathrm{H}_{2} \mathrm{O}$ and CT DNA. The apparent binding constant $\left(K=1 / K_{d}\right)$ was calculated using (5) as described above and obtained as $(2.03 \pm 0.10) \times 10^{3} \mathrm{~mol}^{-1} \mathrm{dm}^{3}$. The apparent binding constant obtained from double reciprocal plot ((6), Figure 4(b)) is $(2.01 \pm 0.16) \times 10^{3} \mathrm{~mol}^{-1} \mathrm{dm}^{3}$. It indicates that there is an excellent agreement between the apparent binding constant values obtained from two different mathematical methods. Inset of Figure 5 shows the plot of normalized increase of $\Delta I / \Delta I_{\max }$ as a function of mole-ratio of DNA to $\mathrm{Na}_{2}\left[\mathrm{Ni}(\mathrm{NaLH})_{2} \mathrm{Cl}_{2}\right] \cdot 2 \mathrm{H}_{2} \mathrm{O}$. The point of intersection of the two straight lines drawn using points before and after saturation gives the stoichiometry or the binding sitesize $(n)$. For $\mathrm{Na}_{2}\left[\mathrm{Ni}(\mathrm{NaLH})_{2} \mathrm{Cl}_{2}\right] \cdot 2 \mathrm{H}_{2} \mathrm{O}$ the " $n$ " value of binding to CT DNA is $(29.02 \pm 1.70)$ bases per molecule of $\mathrm{Na}_{2}\left[\mathrm{Ni}(\mathrm{NaLH})_{2} \mathrm{Cl}_{2}\right] \cdot 2 \mathrm{H}_{2} \mathrm{O}$, that is, $(14.51 \pm 0.85)$ base pairs per molecule of $\mathrm{Na}_{2}\left[\mathrm{Ni}(\mathrm{NaLH})_{2} \mathrm{Cl}_{2}\right] \cdot 2 \mathrm{H}_{2} \mathrm{O}$. Knowing $n$, the intrinsic binding constant $K^{\prime}$, that is, $(K \times n)$ was obtained as $(5.89 \pm 0.10) \times 10^{4} \mathrm{~mol}^{-1} \mathrm{dm}^{3}$. The intrinsic binding constant $\left(K^{\prime}\right)$ and binding site size $(n)$ were also studied using absorption and fluorescence methods. The obtained values of $K^{\prime}$ and $n$ were $6.09 \times 10^{4} \mathrm{~mol}^{-1} \mathrm{dm}^{3}$ and 30 bases per molecule of $\mathrm{Na}_{2}\left[\mathrm{Ni}(\mathrm{NaLH})_{2} \mathrm{Cl}_{2}\right] \cdot 2 \mathrm{H}_{2} \mathrm{O}$ using absorption spectroscopy and $5.92 \times 10^{4} \mathrm{~mol}^{-1} \mathrm{dm}^{3}$ and 32 bases per molecule of $\mathrm{Na}_{2}\left[\mathrm{Ni}(\mathrm{NaLH})_{2} \mathrm{Cl}_{2}\right] \cdot 2 \mathrm{H}_{2} \mathrm{O}$ using fluorescence spectroscopy, respectively [56]. Thus nonlinear curve fit analysis using cyclic voltammetry applied for first time to monitor binding of compounds to DNA generates values that are in excellent agreement with those obtained 
earlier from spectroscopic methods. It should be mentioned here that sodium 1,4-dihydroxy-9,10-anthraquinone2-sulphonate $\left(\mathrm{NaLH}_{2}\right)$ intercalates into DNA base pairs with intrinsic binding constant and binding site size values of $3.44 \times 10^{4} \mathrm{~mol}^{-1} \mathrm{dm}^{3}$ and 16 bases per molecule of $\mathrm{NaLH}_{2}$ respectively [34]. Since the $\mathrm{Ni}$ (II) ion occupies very little space binding of two $\mathrm{NaLH}_{2}$ units to $\mathrm{Ni}$ (II) makes the size of the complex almost double that of the ligand thus further corroborating an observation that the complex binds to $(29.02 \pm 1.70)$ bases with regard to the evaluated binding site of $\mathrm{NaLH}_{2}$ with CT DNA [30]. The binding site size data therefore justifies the ratio of binding of $\mathrm{NaLH}_{2}$ to $\mathrm{Ni}$ (II) in the complex $(2: 1)$ and therefore such studies can also help in determining stoichiometry of the complex when both the ligand and its metal complex bind to DNA under almost identical experimental conditions. The intrinsic binding constant of the $\mathrm{Ni}$ (II) complex obtained from this experiment is $\sim 1.7$ times greater than that found for the interaction of sodium 1,4-dihydroxy-9,10-anthraquinone-2-sulphonate with CT DNA [34] and is also higher than that observed for the interaction of the $\mathrm{Cu}(\mathrm{II})$ complex of $\mathrm{NaLH}_{2}$ with CT DNA [32]. Introduction of a metal ion to the ligand by means of metal complex formation brings about better targeting of DNA $[29,32]$, and this study is actually able to show this. The interaction of $\mathrm{Cu}(\mathrm{II})$ and $\mathrm{Ni}(\mathrm{II})$ complexes were carried out using UV-Vis, fluorescence, and cyclic voltammetry repeatedly, and in all such studies we observed that the results were reproducible and the intrinsic binding constant for the $\mathrm{Cu}(\mathrm{II})$ complex-DNA interaction has a higher value in comparison to that of the $\mathrm{Ni}$ (II) complex. In strong $\mathrm{NaCl}$ media $\left(0.500 \mathrm{~mol} \mathrm{dm}^{-3}\right)$ since the negative charge on $\mathrm{Cu}(\mathrm{II})$ and $\mathrm{Ni}(\mathrm{II})$ complexes and phosphate group of DNA were suppressed, therefore the effect of negative charge on the binding affinity of these metal complexes to DNA was insignificant. The extra electron present in $\mathrm{Cu}(\mathrm{II})$ $\left(3 \mathrm{~d}^{9}\right)$ in comparison to $\mathrm{Ni}(\mathrm{II})\left(3 \mathrm{~d}^{8}\right)$ probably makes the $\mathrm{Cu}$ (II) complex-DNA adduct slightly weaker in binding CT DNA than the Ni(II) complex.

\section{Conclusion}

In aqueous buffer at physiological $\mathrm{pH}$ the $\mathrm{Ni}$ (II) complex of sodium 1,4-dihydroxy-9,10-anthraquinone-2-sulphonate $\left(\mathrm{NaLH}_{2}\right)$, that is, $\mathrm{Na}_{2}\left[\mathrm{Ni}(\mathrm{NaLH})_{2} \mathrm{Cl}_{2}\right] \cdot 2 \mathrm{H}_{2} \mathrm{O}$ undergoes diffusion-controlled one-electron reduction. The redox behavior of sodium 1,4-dihydroxy-9,10-anthraquinone-2sulphonate is modified significantly in the $\mathrm{Ni}(\mathrm{II})$ complexindicating an improvement in biochemical behavior. The $\mathrm{Ni}$ (II) complex intercalates calf thymus DNA which was established by competitive binding study with ethidium bromide. Interaction with CT DNA was monitored by cyclic voltammetry (CV) and binding parameters was determined for the first time using nonlinear curve fit analysis by monitoring the cathodic peak current of the compound. The intrinsic binding constant $\left(K^{\prime}\right)$ and the bind site size for interaction were found to be $(5.89 \pm$ $0.10) \times 10^{4} \mathrm{~mol}^{-1} \mathrm{dm}^{3}$ and $(29.02 \pm 1.70)$ bases per molecule of $\mathrm{Na}_{2}\left[\mathrm{Ni}(\mathrm{NaLH})_{2} \mathrm{Cl}_{2}\right] \cdot 2 \mathrm{H}_{2} \mathrm{O}$, respectively. The bind site size for the interaction of $\mathrm{Ni}(\mathrm{II})$ complex with $\mathrm{CT}$
DNA is double to the same for the ligand $\mathrm{NaLH}_{2}$ under similar experimental condition. The intrinsic binding constant for $\mathrm{Na}_{2}\left[\mathrm{Ni}(\mathrm{NaLH})_{2} \mathrm{Cl}_{2}\right] \cdot 2 \mathrm{H}_{2} \mathrm{O}-\mathrm{CT}$ DNA interaction obtained from this experiment is $\sim 1.7$-times greater than that found for the interaction of sodium 1,4-dihydroxy9,10-anthraquinone-2-sulphonate $\left(\mathrm{NaLH}_{2}\right)$ with CT DNA indicating an improvement in biochemical action of $\mathrm{NaLH}_{2}$ in the form of the metal complex.

\section{Abbreviations}

$\begin{array}{ll}\mathrm{NaLH}_{2}: & \begin{array}{l}\text { Sodium 1,4-dihydroxy-9,10- } \\ \text { anthraquinone-2-sulphonate }\end{array} \\ \mathrm{Na}_{2}\left[\mathrm{Ni}(\mathrm{NaLH})_{2} \mathrm{Cl}_{2}\right] \cdot 2 \mathrm{H}_{2} \mathrm{O}: & \mathrm{Ni}(\mathrm{II}) \text { complex of sodium } \\ & 1,4 \text {-dihydroxy-9,10- } \\ \text { anthraquinone-2-sulphonate }\end{array}$

CT DNA: $\quad$ Calf thymus DNA.

\section{Acknowledgments}

S. Das wishes to thank "Centre for Advanced Studies," and the DST PURSE programme (Government of India) at the Department of Chemistry, Jadavpur University for financial support. P. C. Mandal wishes to thank Intramural MMDDA project at Saha Institute of Nuclear Physics for financial support.

\section{References}

[1] J. G. Hardman, A. G. Gilman, and L. E. Limbird, Goodman and Gilman's The Pharmacological Basis of Therapeutics, McGrawHill Companies, New York, NY, USA, 9th edition, 1996.

[2] K. Reszka, P. Kolodziejczyk, J. A. Hartley, W. D. Wilson, and J. W. Lown, Anthracycline and Anthracenedionebased Anticancer Agents, Elsevier Press, Amsterdam, Netherlands, 1998.

[3] V. J. Ferrans, "Overview of cardiac pathology in relation to anthracycline cardiotoxocity," Cancer Treatment Reports, vol. 62, no. 6, pp. 955-961, 1978.

[4] D. Barasch, O. Zipori, I. Ringel, I. Ginsburg, A. Samuni, and J. Katzhendler, "Novel anthraquinone derivatives with redoxactive functional groups capable of producing free radicals by metabolism: are free radicals essential for cytotoxicity?" European Journal of Medicinal Chemistry, vol. 34, no. 7-8, pp. 597-615, 1999.

[5] K. E. Coldwell, S. M. Cutts, T. J. Ognibene, P. T. Henderson, and D. R. Phillips, "Detection of Adriamycin-DNA adducts by accelerator mass spectrometry at clinically relevant Adriamycin concentrations," Nucleic Acids Research, vol. 36, no. 16, article e100, 2008.

[6] D. A. Gewirtz, "A critical evaluation of the mechanisms of action proposed for the antitumor effects of the anthracycline antibiotics adriamycin and daunorubicin," Biochemical Pharmacology, vol. 57, no. 7, pp. 727-741, 1999.

[7] K. M. Tewey, T. C. Rowe, L. Yang, B. D. Halligan, and L. F. Liu, "Adriamycin-induced DNA damage mediated by mammalian DNA topoisomerase II," Science, vol. 226, no. 4673, pp. 466468, 1984.

[8] M. Gigli, S. M. Doglia, J. M. Millot, L. Valentini, and M. Manfait, "Quantitative study of doxorubicin in living cell nuclei by microspectrofluorometry," Biochimica et Biophysica Acta, vol. 950, no. 1, pp. 13-20, 1988. 
[9] J. Cummings and C. S. McArdle, "Studies on the in vivo disposition of adriamycin in human tumours which exhibit different responses to the drug," British Journal of Cancer, vol. 53, no. 6, pp. 835-838, 1986.

[10] T. Terasaki, T. Iga, Y. Sugiyama, Y. Sawada, and M. Hanano, "Nuclear binding as a determinant of tissue distribution of adriamycin, daunomycin, adriamycinol, daunorubicinol and actinomycin D," Journal of Pharmacobiodyn, vol. 7, no. 5, pp. 269-277, 1984.

[11] H. Fialkoff, M. F. Goodman, and M. W. Seraydarian, "Differential effect of adriamycin on DNA replicative and repair synthesis in cultured neonatal rat cardiac cells," Cancer Research, vol. 39, no. 4, pp. 1321-1327, 1979.

[12] D. C. Ward, E. Reich, and I. H. Goldberg, "Base specificity in the interaction of polynucleotides with antibiotic drugs," Science, vol. 149, no. 3689, pp. 1259-1263, 1965.

[13] E. Calendi, A. DiMarco, M. Reggiani, B. Scarpinate, and L. Valentini, "On physico-chemical interactions between daunomycin and nucleic acids," Biochimica et Biophysica Acta, vol. 103, pp. 25-49, 1965.

[14] W. J. Pigram, W. Fuller, and L. D. Hamilton, "Stereochemistry of intercalation: interaction of daunomycin with DNA," Nature: New biology, vol. 235, no. 53, pp. 17-19, 1972.

[15] Y. Kawakami and A. J. Hopfinger, "Prediction of initial reduction potentials of compounds related to anthracyclines and implications for estimating cardiotoxicity," Chemical Research in Toxicology, vol. 3, no. 3, pp. 244-247, 1990.

[16] F. C. de Abreu, P. A. L. de Ferraz, and M. O. F. Goulart, "Some applications of electrochemistry in biomedical chemistry. Emphasis on the correlation of electrochemical and bioactive properties," Journal of the Brazilian Chemical Society, vol. 13, no. 1, pp. 19-35, 2002.

[17] J. W. Lown, H. H. Chen, and J. A. Plambeck, "Further studies on the generation of reactive oxygen species from activated anthracyclines and the relationship to cytotoxic action and cardiotoxic effects," Biochemical Pharmacology, vol. 31, no. 4, pp. 575-581, 1982.

[18] R. L. Blankespoor, E. L. Kosters, A. J. Post, and D. P. VanMeurs, "Substituent effects upon the peak potentials and reductive cleavage rate constants of hydroxy- and methoxysubstituted 9,10-anthraquinones in 50\% aqueous $\mathrm{CHCN}$ : do they correlate?" Journal of Organic Chemistry, vol. 56, no. 4, pp. 1609-1614, 1991.

[19] A. Kumbhar, S. Padhye, and D. Ross, "Cytotoxic properties of iron-hydroxynaphthoquinone complexes in rat hepatocytes," BioMetals, vol. 9, no. 3, pp. 235-240, 1996.

[20] A. Bartoszek, "Metabolic activation of adriamycin by NADPH-cytochrome P450 reductase; overview of its biological and biochemical effects," Acta Biochimica Polonica, vol. 49, no. 2, pp. 323-331, 2002.

[21] S. Das, A. Saha, and P. C. Mandal, "Radiosensitization of uracil by $\mathrm{Cu}(\mathrm{II})$ and $\mathrm{Ni}(\mathrm{II})$ complexes of 1,2 dihydroxy 9,10 anthraquinone," Journal of Radioanalytical and Nuclear Chemistry, vol. 196, pp. 57-63, 1996.

[22] S. Das, A. Saha, and P. C. Mandal, "Radiation-induced doublestrand modification in calf thymus DNA in the presence of 1,2-dihydroxy-9,10-anthraquinone and its $\mathrm{Cu}(\mathrm{II})$ complex," Environmental Health Perspectives, vol. 105, no. 6, pp. 14591462, 1997.

[23] S. Das and P. C. Mandal, "Influence of $\mathrm{Ni}(\mathrm{II})$ and $\mathrm{Fe}(\mathrm{III})$ complexes of 1,2 dihydroxy 9,10 anthraquinone on the modification in calf thymus DNA upon gamma irradiation," Radiation Physics and Chemistry, vol. 78, no. 1, pp. 37-41, 2009.
[24] J. A. Plambeck and J. W. Lown, "Electrochemical studies of antitumor antibiotics," Journal of the Electrochemical Society, vol. 131, no. 11, pp. 2556-2563, 1984.

[25] J. Kapuscinski and Z. Darzynkiewicz, "Relationship between the pharmacological activity of antitumor drugs ametantrone and mitoxantrone (novantrone) and their ability to condense nucleic acids," Proceedings of the National Academy of Sciences of the United States of America, vol. 83, no. 17, pp. 6302-6306, 1986.

[26] S. Rossi, C. Tabolacci, A. Lentini et al., "Anthraquinones danthron and quinizarin exert antiproliferative and antimetastatic activity on murine B16-F10 melanoma cells," Anticancer Research, vol. 30, no. 2, pp. 445-449, 2010.

[27] P. Varadwaj, K. Misra, A. Sharma, and R. Kumar, "Mitoxantrone: an agent with promises for anticancer therapies," Electronic Journal of Biology, vol. 6, pp. 36-42, 2010.

[28] C. Menke, T. Goncharov, L. Qamar et al., "TRAIL receptor signaling regulation of chemosensitivity in vivo but not in vitro," PLoS ONE, vol. 6, pp. 1-8, 2011.

[29] H. Beraldo, A. Garnier-Suillerot, L. Tosi, and F. Lavelle, "Iron(III)-adriamycin and iron(III)-daunorubicin complexes: physicochemical characteristics, interaction with DNA, and antitumor activity," Biochemistry, vol. 24, no. 2, pp. 284-289, 1985.

[30] M. M. L. Fiallo and A. Garnier-Suillerot, "Metal anthracycline complexes as a new class of anthracycline derivatives. Pd(II)adriamycin and $\mathrm{Pd}(\mathrm{II})$-daunorubicin complexes: physicochemical characteristics and antitumor activity," Biochemistry, vol. 25, no. 4, pp. 924-930, 1986.

[31] S. Das, A. Saha, and P. C. Mandal, "Studies on the formation of $\mathrm{Cu}(\mathrm{II})$ and $\mathrm{Ni}(\mathrm{II})$ complexes of 1,2-dihydroxy-9,10anthraquinone and lack of stimulated superoxide formation by the complexes," Talanta, vol. 43, no. 1, pp. 95-102, 1996.

[32] P. S. Guin, S. Das, and P. C. Mandal, "Studies on the formation of a complex of $\mathrm{Cu}(\mathrm{II})$ with sodium 1,4-dihydroxy-9,10anthraquinone-2-sulphonate-an analogue of the core unit of anthracycline anticancer drugs and its interaction with calf thymus DNA," Journal of Inorganic Biochemistry, vol. 103, no. 12, pp. 1702-1710, 2009.

[33] P. S. Guin, S. Das, and P. C. Mandal, "Electrochemical reduction of sodium 1,4-dihydroxy-9,10-anthraquinone-2sulphonate in aqueous and aqueous dimethyl formamide mixed solvent: a cyclic voltametric study," International Journal of Electrochemcal Science, vol. 3, pp. 1016-1028, 2008.

[34] P. S. Guin, S. Das, and P. C. Mandal, "Sodium 1, 4-dihydroxy9, 10-anthraquinone- 2-sulphonate interacts with calf thymus DNA in a way that mimics anthracycline antibiotics: an electrochemical and spectroscopic study," Journal of Physical Organic Chemistry, vol. 23, no. 6, pp. 477-482, 2010.

[35] P. S. Guin, S. Das, and P. C. Mandal, "Electrochemical reduction of quinones in different media: a review," International Journal of Electrochemcal Science, vol. 2011, pp. 1-22, 2011.

[36] P. Das, P. S. Guin, P. C. Mandal, M. Paul, S. Paul, and S. Das, "Cyclic voltammetric studies of 1,2,4-trihydroxy-9,10anthraquinone, its interaction with calf thymus DNA and anti-leukemic activity on MOLT-4 cell lines: a comparison with anthracycline anticancer drugs," Journal of Physical Organic Chemistry. In press.

[37] P. S. Guin, S. Das, and P. C. Mandal, "Interaction of 1,4dihydroxy-9,10-anthraquinone with Calf thymus DNA: a comparison with anthracycline anticancer drugs," Journal of Solution Chemistry, vol. 40, no. 3, pp. 492-501, 2011. 
[38] N. Li, Y. Ma, C. Yang, L. Guo, and X. Yang, "Interaction of anticancer drug mitoxantrone with DNA analyzed by electrochemical and spectroscopic methods," Biophysical Chemistry, vol. 116, no. 3, pp. 199-205, 2005.

[39] J. R. Lancaster Jr., Ed., Bioinorganic Chemistry of Nickel, WileyVCH, New York, NY, USA, 1988.

[40] S. Ciurli and S. Mangani, "Nickel containing enzymes," in Hand Book of Metallo Proteins, I. Bertini, A. Sigel, and H. Sigel, Eds., chapter 4, Marcel Dekker, New York, NY, USA, 2001.

[41] P. J. O'Brien, "Molecular mechanisms of quinone cytotoxicity," Chemico-Biological Interactions, vol. 80, no. 1, pp. 1-41, 1991.

[42] A. Nemeikaité-Čéniené, E. Sergediené, H. Nivinskas, and N. Čénas, "Cytotoxicity of natural hydroxyanthraquinones: role of oxidative stress," Zeitschrift fur Naturforschung - Section C, vol. 57, no. 9-10, pp. 822-827, 2002.

[43] P. S. Guin, S. Das, and P. C. Mandal, "Formation and characterization of $\mathrm{Ni}$ (II) complex of sodium 1,4-dihydroxy9,10-anthraquinone-2-sulphonate, an analogue of the core unit of anthracycline antibiotics, by different spectroscopic techniques," International Journal of Pure and Applied Chemistry, vol. 3, pp. 283-290, 2008.

[44] M. D. Vaira, P. Orioli, F. Piccioli, B. Bruni, and L. Messori, "Structure of a terbium(III)-quinizarine complex: the first crystallographic model for metalloanthracyclines," Inorganic Chemistry, vol. 42, no. 10, pp. 3157-3159, 2003.

[45] W. Lang and R. Zander, "Physiological HEPES buffer proposed as a calibrator for $\mathrm{pH}$ measurement in human blood," Clinical Chemistry and Laboratory Medicine, vol. 37, no. 5, pp. 563$571,1999$.

[46] T. Mukherjee, E. J. Land, A. J. Swallow, P. M. Guyan, and J. M. Bruce, "Successive addition of electrons to sodium quinizarin2 - and -6-sulphonate in aqueous solution. A pulse and $\gamma$ radiolysis study," Journal of the Chemical Society, Faraday Transactions 1, vol. 84, no. 8, pp. 2855-2873, 1988.

[47] A. J. Bard and L. R. Faulkner, Electrochemical Methods: Fundamentals and Applications, John Wiley \& Sons, Singapore, Asia, 2001.

[48] J. A. Pachter, C. H. Huang, V. H. Du Vernay Jr., A. W. Prestayko, and S. T. Crooke, "Viscometric and fluorometric studies of deoxyribonucleic acid interactions of several new anthracyclines," Biochemistry, vol. 21, no. 7, pp. 1541-1547, 1982.

[49] A. J. Bard, M. T. Cater, and M. Rodoriguez, "Voltammetric studies of the interaction of metal chelates with DNA. 2. tris-chelated omplexes of cobalt(III) and iron(II) with 1,10phenanthroline and 2,2'-bipyridine," Journal of the American Chemical Society, vol. 111, pp. 8901-8911, 1989.

[50] M. J. Waring, "DNA modification and cancer," Annual Review of Biochemistry, vol. 50, pp. 159-192, 1981.

[51] A. Radi, M. A. El Ries, and S. Kandil, "Electrochemical study of the interaction of levofloxacin with DNA," Analytica Chimica Acta, vol. 495, no. 1-2, pp. 61-67, 2003.

[52] S. Roy, R. Banerjee, and M. Sarkar, "Direct binding of $\mathrm{Cu}(\mathrm{II})$ complexes of oxicam NSAIDs with DNA backbone," Journal of Inorganic Biochemistry, vol. 100, no. 8, pp. 1320-1331, 2006.

[53] S. Chakrabarti, B. Bhattacharyya, and D. Dasgupta, "Interaction of mithramycin and chromomycin $\mathrm{A}_{3}$ with d(TAGCTAGCTA $)_{2}$ : role of sugars in antibiotic-DNA recognition," Journal of Physical Chemistry B, vol. 106, no. 27, pp. 6947-6953, 2002.

[54] M. A. Mir, S. Majee, S. Das, and D. Dasgupta, "Association of chromatin with anticancer antibiotics, mithramycin and chromomycin A," Bioorganic and Medicinal Chemistry, vol. 11, no. 13, pp. 2791-2801, 2003.
[55] T. Deba, D. Choudhury, P. S. Guin, M. B. Sahaa, G. Chakrabartib, and S. Das, "A complex of $\mathrm{Co}(\mathrm{II})$ with 2hydroxyphenyl-azo-2-naphthol (HPAN) is far less cytotoxic than the parent compound on A549-lung carcinoma and peripheral blood mononuclear cells: reasons for reduction in cytotoxicity," Chemico-Biological Interactions, vol. 189, pp. 206-214, 2011.

[56] P. S. Guin, S. Das, and P. C. Mandal, "Formation of a novel complex of $\mathrm{Ni}(\mathrm{II})$ with the anticancer drug adriamycin and its interaction with calf thymus DNA: A spectroscopic study comparing it with the $\mathrm{Ni}$ (II) complex of sodium 1,4dihydroxy-9,10-anthraquinone-2-sulphonate," in Proceedings of the International Conference on Physics Biology Interface (ICPBI '09), p. 92, Kolkata, India, December 2009. 


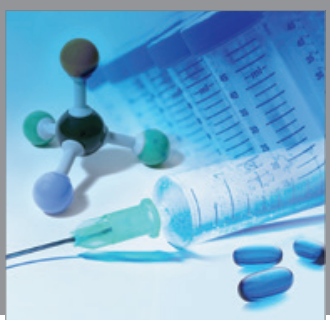

International Journal of

Medicinal Chemistry

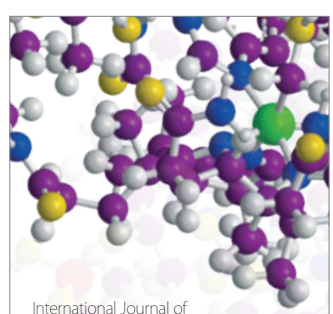

Carbohydrate Chemistry

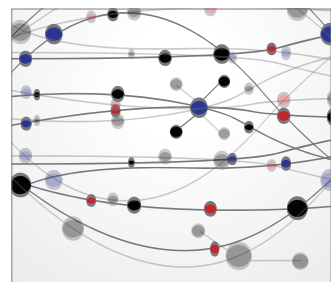

The Scientific World Journal
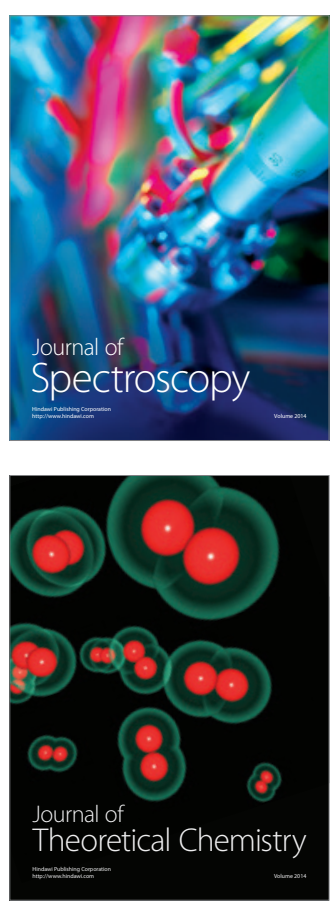
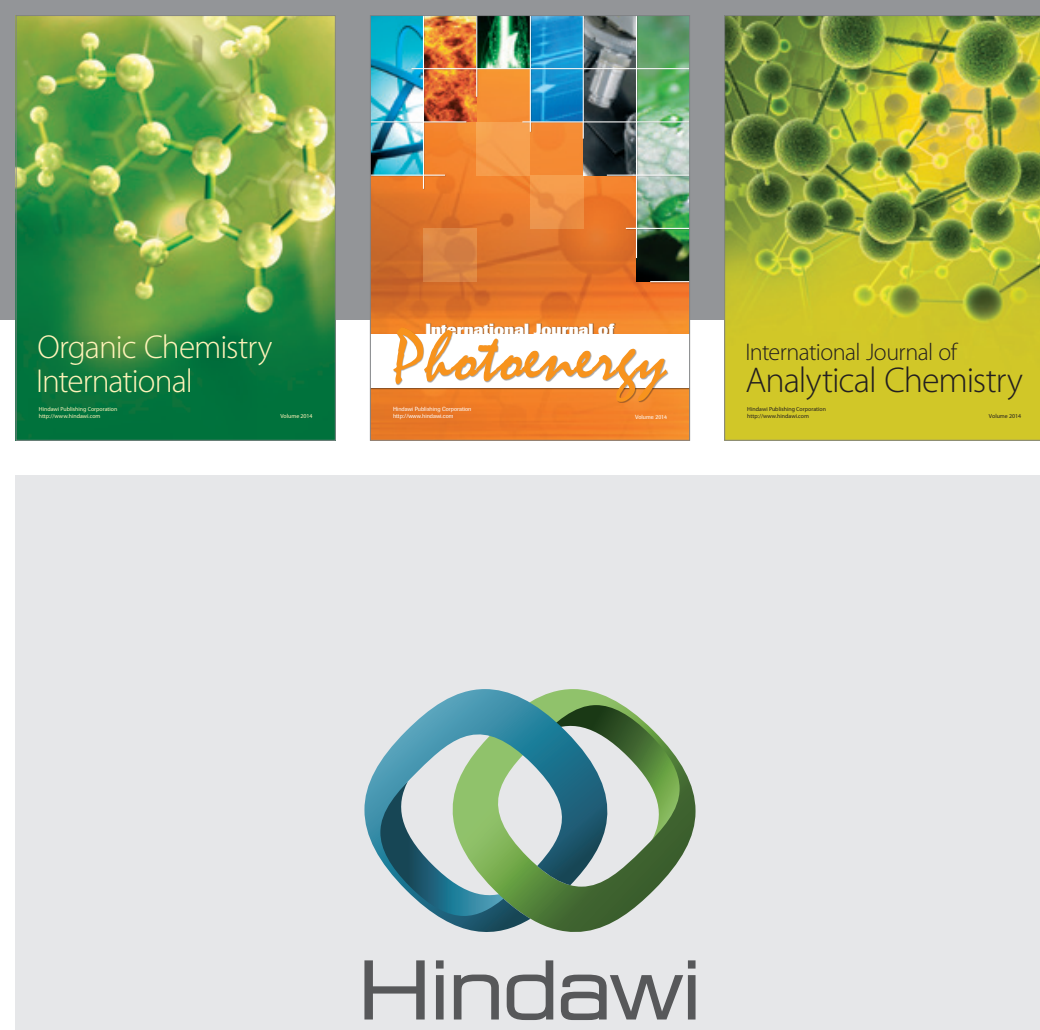

Submit your manuscripts at

http://www.hindawi.com
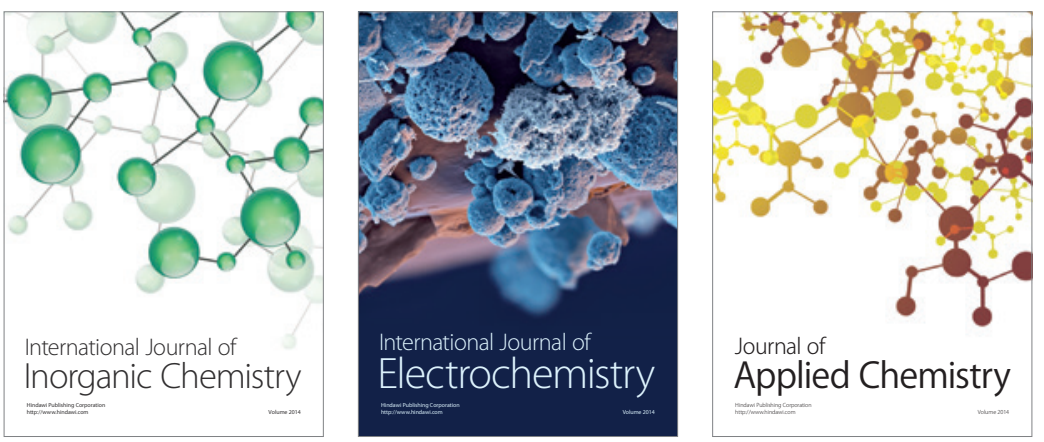

Journal of

Applied Chemistry
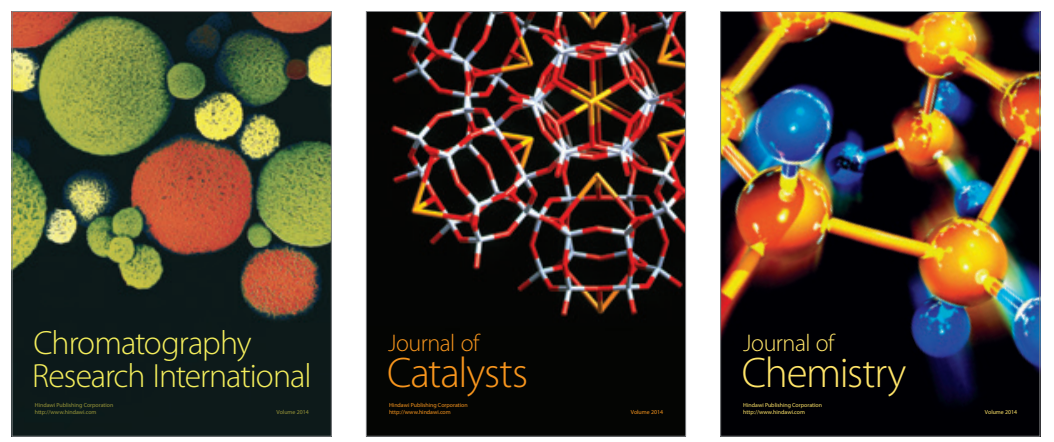
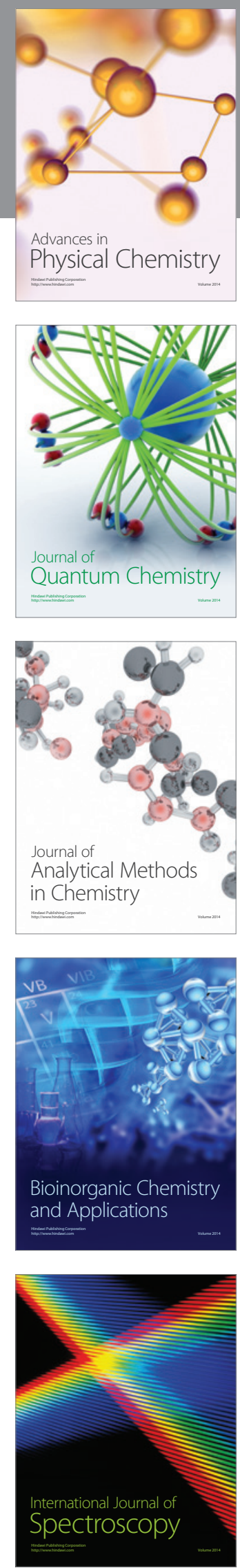